\title{
THE LIMINALITY OF LITURGY ${ }^{1}$
}

\author{
Johan Cilliers \\ Practical Theology and Missiology \\ Stellenbosch University
}

\begin{abstract}
This paper proposes that the church cannot be edified without taking cognizance of the role and function of liturgy. Whilst liturgical experimentation seems to be the rule of the day, a plea is made for responsible liturgical renewal that does not follow the opportunism of fashionable liturgical cosmetics. This entails a deepened understanding of the liminality of liturgy, especially in this time of transition in South Africa. Some key concepts of a liminal liturgy are expanded on, namely: lament, re-framing, and anticipation.
\end{abstract}

Key Words: Liturgy, Liminality, Lament, Reframing, Anticipation

\section{Beware: You are now Entering the Liminal Zone}

Preaching is basic and central for building up a congregation (Nel 2001:5). This does not mean that preaching alone can build up the people of God to be and to do what He intended them to, but that the latter indeed can also not happen without preaching. Preaching should, however, not be understood in abstraction from liturgy: being part of liturgy, it plays a paramount role in the formation and motivation of communities of faith, moving them in the direction that God has in mind for them as his people in a given context.

If we intend to build up the church to fulfill her calling, especially in this time of transition in South Africa, we need to revisit our understanding and practices of liturgy. It would seem as if we are presently going through a phase of homiletical and liturgical experimentation as never before, with the tendency to develop in (superficial) width, but not in (theological) depth (cf. Cilliers 2007a:54). There seems to be a fine line between responsible renewal, following the calling of ecclesia semper reformanda, and the opportunism of fashionable liturgical cosmetics, which Leonora Tubs Tisdale calls the movement from saying 'Holy, Holy, Holy', to saying 'nice, nice, nice' (Tisdale 2001:182). Ganzevoort (2004:152) also feels quite strongly about this, and articulates as follows:

This revival of rituals has become the major feature of present day religion, overwhelmingly manifest even in mainstream Calvinism. Preachers have evolved from Verbi Divini Minister into liturgists and priests. The sermon is less proclamation and more experience or event. More and more rituals have entered the congregation, both on the collective level of worship and on the individual level of pastoral care and counselling. Some of these rituals lean heavily on the reformed tradition, others scrounge unabashed from a variety of Christian and non-Christian sources, as well as from the realm of therapy. All that seems to matter is the question how we can aid people in experiencing God, the divine, the supernatural, meaning, or whatever.

Edited version of a paper published in A Faithful Witness. Essays in honour of Malan Nel, (ed.) H Pieterse and C Thesnaar, Wellington: Bybel Media, 2009:167-181. Published here with permission of the editors. 
I am of the opinion that South Africa, being in a phase of transition, needs a liturgy of (or: in) transition, and this has nothing to do with following the fashionable trend. Congregations that need to be built up find themselves, knowingly or unknowingly, in a country that has left behind a painful past, but has not yet reached its destination. South Africans at present exist within an in-between space, where we have achieved political freedom, but at the same time are still struggling with issues such as poverty, HIV and AIDS, unemployment, crime, corruption, and the collapse of certain value systems. We have indeed entered a transitional state, a liminal space, calling, amongst other things, for a rethinking of the way we worship.

Of course, liminality as such is no new concept. It was already coined in 1909 by Arnold van Gennep (Les rites de passage), when he used the term limen (threshold, outlines, margins) to describe human rituals marking the passage from one life cycle to the other. Since then several other authors have made use of it, especially Victor Turner, who distinguishes between the phases of separation, liminality, and aggregation. He also made use of the idea of 'pilgrimage' - which essentially is anti-structure and anti-status quo - but ultimately ends up with the formation of a new community ('communitas'), which in turn can become a new structure or new status quo that eventually might need to be deconstructed (1978:64 f.).

Paul Tournier refers to liminality as being en route: having left your home and not yet having arrived at your destination (1968:163). It is the experience of being in limbo. Eugene Peterson uses the striking metaphor of a trapeze artist swirling through space, in transit through mid-air, having been released from the arms of fellow trapeze artists, and expecting to be caught in the firm and faithful grip of those waiting (2000:20).

Essentially liminality implies an ambiguous phase between two situations or statuses. Often this in-between space or liminal displacement is filled with potential and/or danger. It breathes “... a sense of displacement, that sense of being in no man's land, where the landscape appears completely different, there is no discernable road map, and where the journeyer is jolted out of normalcy" (Franks and Meteyard 2007:216).

Characteristically the liminal phase is constituted by the convergence or interweaving of qualities of both categories between which it is sandwiched: "Since the liminal is neither fully one type of space (category) nor the other, it will take on aspects of both; it is this indeterminacy of quality and therefore predictability that creates the aspect of danger" (Kunin 1989:30).

Liminality therefore represents a highly creative phase or space, where the combination of new forms and relations is possible. This heightened sense of creative possibility is articulated poignantly by Sang Hyun Lee, reflecting on the experiences of Koreans in borderline situations in America:

Released for a moment from social structure, persons in liminality can relate to each other simply and fully as human beings and experience an intense quality of human communion usually impossible in structured society... It is in such moments of liminal communitas... that persons can be free enough to reflect on their lives or society, envision new ideas and ways of doing things, and dream new dreams. Powerful rituals latent with ultimate meanings, new or old insights, and alternative ways of interpreting reality can have their powerful impact on persons in liminal communitas (2001:98).

In liminality the borders remain porous, open to all sides. Here is given the possibility of (new) revelation and transformation, of dying and living, hope and resurrection. In a 
nutshell: in the liminal space one experiences both the fullness and emptiness of presence and absence (cf. Friedland and Hecht 2006:35). ${ }^{2}$

Liminality is no stranger to the life of faith. After all, scriptures also seem to be filled with experiences of, and metaphors for, liminality - the most representative probably being the tomb, the wilderness and the exile. Each of these scriptural metaphors articulates a different nuance of liminality: the tomb speaks of grief and pain (lament) that is associated with the leaving behind of old structures of identity and security; the wilderness suggests the possibility of having new and surprising encounters with God (re-framing); the exile sharpens the sense of longing, of looking forward to the alternative of the promised land (anticipation). All of these experiences, however, have a common denominator, namely "... the need to let go of, leave behind or even be forcibly expelled from old ascendant forms of self-definition and identity so that God can be found in ways never before experienced. It is thus in the place of liminality, when stripped of all structures of support and security, that the pilgrim and God are free to encounter each other in new and life changing ways" (Franks and Meteyard: 220). Liminality is without question an integrate part of the life of faith, and therefore also of the life of worship. ${ }^{3}$

2 Kierkegaard understood this grappling with the God of the gaps, this paradox of the absent present One, this yearning for the inaudible voice of the silent speaker whom we call God, when he prayed:

Father in heaven! You speak to humans in many ways: You, to whom all wisdom and intellect belongs, You wish to make Yourself conceivable to us anew. Oh, and also when You remain silent, then You still indeed speak to us; because also He who speaks sometimes remains silent to give his children the opportunity to have their say; also He that speaks sometimes remains silent to test his beloveds; also He who speaks sometimes remains silent to make the moment of understanding so much more profound when it comes. Father in heaven, is this not so? Oh, the time of silence, when a person stands alone and deserted, because we do not hear Your voice, then we feel that the separation will be forever. Oh, the time of silence, when a person thirsts in the desert, because we do not hear Your voice, and it seems as though we have been entirely forgotten! Father in heaven, then it is but a short pause in the coherence of the dialogue between You and us. So allow this also to be blessed, this silence of Yours, like every word of Yours to us. Do not let us forget that You also then speak, when You are silent; give us this consolation: that you remain silent out of love, just as You also speak out of love, so that now, whether You are silent and whether You speak, You are still the same Father, who acts with the same Fatherliness, whether you now lead us through Your voice, and whether You now teach us with Your silence (1949:210).

3 This in-between state of faith is already reflected in the experience of the early Christians, as witnessed to in the well known letter to Diogenetos (2nd century). An excerpt: "Christians are indistinguishable from other men either by nationality, language or customs. They do not inhabit separate cities of their own, or speak a strange dialect, or follow some outlandish way of life. Their teaching is not based upon reveries inspired by the curiosity of men. Unlike some other people, they champion no purely human doctrine. With regard to dress, food and manner of life in general, they follow the customs of whatever city they happen to be living in, whether it is Greek or foreign. And yet there is something extraordinary about their lives. They live in their own countries as though they were only passing through. They play their full role as citizens, but labor under all the disabilities of aliens. Any country can be their homeland, but for them their homeland, wherever it may be, is a foreign country. Like others, they marry and have children, but they do not expose them. They share their meals, but not their wives. They live in the flesh, but they are not governed by the desires of the flesh. They pass their days upon earth, but they are citizens of heaven. Obedient to the laws, they yet live on a level that transcends the law. Christians love all men, but all men persecute them. Condemned because they are not understood, they are put to death, but raised to life again. They live in poverty, but enrich many; they are totally destitute, but possess an abundance of everything. They suffer dishonor, but that is their glory. They are defamed, but vindicated. A blessing is their answer to abuse, deference their response to insult. For the good they do they receive the punishment of malefactors, but even then they rejoice, as though receiving the gift of life. They are attacked by the Jews as aliens, they are persecuted by the Greeks, yet no one can explain the reason for this hatred." 
In the light of the urgency of a liturgy that edifies congregations in a responsible manner in the contemporary South African context, I would like to revisit the concept of liminality in terms of some ${ }^{4}$ of its keywords, namely lament, re-framing, and anticipation.

\title{
Liminal Liturgy as Lament
}

When one is brought into the space of liminality, experiences of fragility and the transience of life are bound to follow. When so-called secure structures fall apart, one no longer can escape from reality. Liminality leads to lament, and this is probably one of the better things that can happen to you, and indeed, a church. For, if one laments in liminality, you no longer avoid, or hide, or mask (with the help of secure structures!) that which must be brought into light. Whilst lament does not easily find a place in existing and secure structures, and indeed is often actively kept out, the experience of liminal displacement literally cries out for, and with, lament.

The language of lament is, however, more than a public outcry - however justified that may also be. It is more than psychological or religious self-pity. It is a voicing of suffering of individuals or a community within the community of believers, in the presence of God. Ackermann formulates this movingly: "Lament is more than railing against suffering, breast-beating or a confession of guilt. It is a coil of suffering and hope, awareness and memory, anger and relief, desires for vengeance, forgiveness and healing. It is our way of bearing the unbearable, both individually and communally. It is a wailing of the human soul, a barrage of tears, reproaches, petitions, praise and hopes which beat against the heart of God. It is, in essence, supremely human” (2001:26).

The Bible, of course, speaks openly of lament. In both the Old and New Testaments we find lament to be part and parcel of the people of God's way of worship, even of the core of their relationship with God:

\begin{abstract}
In both the Old and New Testament the lament is a very natural part of human life; in the Psalter it is an important and inescapable component of worship and of the language of worship. In the Old Testament there is not a single line which would forbid lamentation or which would express the idea that lamentation had no place in a healthy and good relationship with God. But I also know of no text in the New Testament which would prevent the Christian from lamenting or which would express the idea that faith in Christ excluded lamentation from man's relationship with God (Westermann 1974:25).
\end{abstract}

The language of lament articulates those feelings and experiences on the edges of our existence, feelings and experiences of liminality that disrupt our equilibrium and shatter our mediocrity, and kindle in us a longing for transcendence. Using this language, we can speak out in an honest and liberating manner about the rawness of life, in contrast to conventional speech which is often nothing else but a linguistic cover-up. The uniqueness of the language of lament lies in the fact that through it we address God, even if it is an abrasive and argumentative way of protesting against that which caused the lament (cf. Cilliers 2007b:155-176).

Whilst celebration extols the dimension of the 'already' in the reign of God's Kingdom, lament expresses the 'not yet' (cf. Tisdale $182 \mathrm{f}$.). Worship services should express both these dimensions, but it should also be said that we perhaps have a tendency to skip over

As also reflected in the abovementioned scriptural metaphors. Of course there are more than those quoted above, for instance anti-structure (prophecy), new community (communitas), and possibility (imagination). 
the 'not yet' in favour of the 'already'. Then the latter becomes triumphalistic, and indeed a form of escapism from reality.

In this transitional time in South Africa, we have more than enough to lament about. It is even a valid question whether we have faced our past adequately enough, and especially whether we have created liturgical spaces where this could be done. This is an issue that cannot be settled with a number of official declarations ${ }^{5}$, but which must be worked through in continuous liturgical settings in a process of questioning and listening, of remembrance and repetition, instead of forgetting and pushing aside (Richter-Böhne 1989:13; cf. also Cilliers 2006:11).

Congregations cannot be built up if they do not (re)learn the language of lament. Then why do we find it so difficult to speak this language? Many reasons could be proposed in this regard: the residues of Greek Stoicism still being with us, the influence of a successdriven society that does not allow failure and therefore lament, our one-sided understanding of soteriology (confusing suffering from sin with confession of sin), our selective use of biblical texts, our reduction of the dynamics of the texts that we do use, our misunderstanding of what biblical patience entails, and, ultimately, our highly abbreviated Godimages (cf. Cilliers 2007b:155-176).

It is important to realize that lamenting is not synonymous with religious introversion. It would seem that many congregations are at present suffering from exactly this. Whilst many (mostly white) South Africans have immigrated to other countries, those remaining in South Africa seem to be emigrating inwardly (cf. Durand 2002:60). This tendency to emigrate inwardly is a symptom of a theology and therefore also liturgy that by-pass reality, and skip over the difficult calling of facing and indeed transforming society.

Essentially, lament is a profound ethical act; the beginning of a social and political praxis; the onset of the destabilization of the status quo. Lament is subversive by nature, as it refuses to accept that things that are wrong should remain like that. In lament, we face and confess the ongoing injustices; the destructive spirals of violence, whether they are brutal or subtle; the wrongs of the past, as well as the painful lingering thereof in the present. In contemporary South African liturgy, there can be no other route.

\section{Liminal Liturgy as Re-framing}

Perhaps the reason why lament is so neglected is, as already suggested above, because it presupposes certain God images with which we feel uncomfortable. Brueggemann (1997: 317-403) is of the opinion that certain biblical texts are no-go areas for exactly this reason. As counter-testimonies or cross-examinations of Israel's core testimony, they reveal sides of Jahwe that hardly fit in with conventional theological and sermonic language. They speak of the hiddenness, ambiguity and negativity of God. We choose not to preach on this, because we do not understand that we need these images of God, held in tension with others, if we are to make sense of reality with all its experiences of disorientation, chaos and death.

In times of liminality, as we are experiencing at present, the certainties of set Godimages are often shattered, along with others. This can indeed be a dangerous, even devastating experience, filled with the tension of paradox, ambiguity, and ambivalence, as choices that are made within this time in limbo, might have far-reaching implications for and in the future.

The Dutch Reformed Church has done so on a number of occasions, also formally during meetings of its General Synod, first in 1986, and again in 1990. 
We have come from an era of certainties, of securocracy, which was also theologically and liturgically entrenched. The structures that we have left behind us operated with a Godimage that changed history into nature, contingency into stringency, and movement into monuments. Truth became subservient to national security (cf. Cilliers 2006:68). Gracefully, we have been released from this entrenchment of the past into our present state of liminality, and the challenge now is to create liturgies that envision and embody new, perhaps surprising and disturbing, but still liberating and healing images of God.

As liminality offers a creative space where hitherto unknown and unthought-of possibilities and interactions are opened up, a liminal liturgy has the potential to tap into exactly these existential experiences of re-framing. In this regard the role and impact of scriptures is of paramount importance. Scriptures as such could be seen as documents that originated from liminal experiences, within liminal displacement (cf. Mouton 2007:80). It documents the struggle of believers to articulate transformed and transforming situations, being en route with the living God Himself. Therefore old traditions and interpretations and even God-images had to be re-interpreted all the time, on the one hand remembering the past, but on the other hand also being taken forward by the living God into a new future. This calls for the re-arrangement and re-appropriation of existing religious structures and traditions, a re-configuration of their religious beliefs, and ultimately a re-imagination and re-naming of their God-images.

Such an act of re-framing is off course a risky undertaking. It demands prayer. It calls for prophecy. It articulates the fact that the hour of salvation has struck, and thus drives time ahead (cf. 1 Pt 3:12a). But there is no other way. God is eternal, but theology not. A liturgy that never changes, is never reconfigured and re-appropriated, may be 'in order', but it is false, not faithful to the times, and ultimately not faithful to the biblical witnesses of the living God.

Actually, a liturgy that does not understand the art of dynamic and continuous reformation represents a way of escaping from time, from the continuation of time, and from God's self-revelation in time; it is a grasp back into history to avoid contemporary realities and the future. It represents a particular form of anti-prophecy that does not dare to jump ahead, but rather arrests time and reproduces history. In this arrest and reproduction, God becomes comparable and inactive. However, God is precisely the opposite: $\mathrm{He}$ is the incomparable active One (Wolf 1969:400ff), because He is distinct from all gods, powers of nature, historical events, or the world's primeval functions. He is not similar to the world's objects and powers; also not identical to people, their groups or human behaviour. $\mathrm{He}$ is the free ground of all that exists and takes place. In no way is He subject to repetition, but is the living One who frequently is defined as such, and only by Himself - but amazingly enough, sometimes also through the transient words and symbols of fragile people, living and worshipping the eternal God in the 'in-between' times of transition (cf. Cilliers 2006:25-26).

\section{Liminal Liturgy as Anticipation}

Previously we mentioned that we seem to have a tendency to skip over the 'not yet' in favour of the 'already' in the reign of God's Kingdom (cf. 2). The experience of liminality enables us to appreciate the importance of the tension between these two states of reality; as a matter of fact, these two states or phases constitute the ultimate experience of liminality. It could also be described by the word anticipation, or in biblical terms: hope. 
Anticipation is more than just day dreaming about a longed for tomorrow; it is more than wishful thinking. It is imagining the future in such a way that the future becomes present, or rather: it is rediscovering the fact that the future is already present, already amongst us. Anticipation consists of looking towards the future, on the basis of the reality of this future's presence. It derives its energy exactly from this ambiguity and ambivalence: the presence of the future, and the future of the presence.

Therefore a liminal liturgy should not only lament; it should also celebrate. It celebrates on the grounds of the reality (presence) of that which is hoped for. This celebration, however, is a far cry from a superficial frivolity or naïve fleeing from reality. It celebrates within, and against the harshness of life, but also in view of the reality of the future that has already begun, as ultimately embodied in the resurrection of Jesus Christ. Liturgical anticipation in times of transition knows about lament, about grieving for change, ${ }^{6}$ but it also knows about celebration, about change that has already been wrought.

This paradoxical nature of liminal anticipation finds its most adequate articulation in metaphorical speech. The Greek word metaphora (meta and phora) literally means to carry over, or transfer. McFague describes metaphors as "...a word used in an unfamiliar context to give us new insight; a good metaphor moves us to see our ordinary world in an extraordinary way" (1978:4).

Without metaphors we cannot talk about the unseen realities of the present future; we cannot talk about God. The referential character of metaphors enables us to talk about the Unknown in terms of the known. They function as bridge builders, but in such a manner that the realities on both sides of the bridge are kept in a meaningful and creative tension with one another. Metaphors do not only 'describe' things, but rather instigate a two-way traffic across the bridge, transferring reciprocal meaning, but not in the sense of a secure set of truths or certainties; rather as an open highway whereon surprising discoveries can be made. Metaphors create spaces and tensions, wherein meaning 'happens'. This is perhaps the most striking characteristic of metaphors: they do not have set meanings and their effect cannot be predicted precisely (Ricoeur 1975:152 f.).

Metaphors offer us an imaginative means to anticipate different, better alternatives. They underline the fact that we always operate with a preliminary (liminal) understanding of God and reality (Van Niekerk 1994:286), and this preliminary understanding is best articulated in metaphorical language. The uniqueness of metaphors lies therein that they operate with the paradoxical presupposition that something can simultaneously be and not be, indeed exist 'already' and 'not yet' (Ricoeur 1979:27).

Metaphorical language expresses something of the uniqueness of liminal liturgy. It articulates the experiences of 'in-between' times: the rising from every form of bondage, therefore no longer there; but also still in the process of becoming what we should be, therefore not yet there. It expresses lament (how long must we still wait?), but also reframing (finding new meaning in life); and especially anticipation (the freedom of the future being already here, in nuce).

In short: metaphorical language captivates the essence of what a church that is being built up in the 'in-between' times of transition should look like. It gives voice to liminal liturgy.

Cf. the striking title of the book by Arbuckle: Grieving for change. A spirituality for refounding communities. Strand, London: Cassell Publishers Limited. 


\section{BIBLIOGRAPHY}

Ackermann, D 2001. Tamar's cry: re-reading an ancient text in the midst of an HIV/AIDS pandemic. EFSA..

Arbuckle, GA 1991. Grieving for change. A spirituality for refounding communities. Strand, London: Cassell Publishers Limited.

Brueggemann, W 1997. Theology of the Old Testament. Testimony, Dispute, Advocacy. Minneapolis: Fortress Press.

Cilliers, JH 2006. God for us? An analysis and evaluation of Dutch Reformed preaching during the Apartheid years. Stellenbosch: Sun Press.

Cilliers, JH 2007a. Binne die Kring-Dans van die Kuns. Die betekenis van Estetika vir die Gereformeerde Liturgie. Stellenbosch: SunPress.

Cilliers, JH 2007b. Preaching as language of hope in a context of HIV and AIDS. Preaching as a Language of Hope. Studia Homiletica 6, Ed Cas Vos, Lucy L Hogan and Johan H Cilliers. Pretoria: Protea Book House 2007. 155-176.

Durand, J 2002. Ontluisterde Wêreld. Die Afrikaner en sy kerk in ' $n$ veranderende SuidAfrika. Wellington: Lux Verbi. BM.

Franks, A and Meteyard J 2007. Liminality: The Transforming Grace of In-between Places. The Journal of Pastoral Care and Counseling Vol. 61 No. 3 Fall 2007, 215-222.

Friedland, R and Hecht, RD 2006. The powers of place. Religion, Violence, Memory, and Place. Ed. Stier, OB and Landres, JS. Indiana University Press: Bloomington and Indianapolis, 17-35.

Ganzevoort, RR 2004. Rituals and the decay of the Word. In Passion of Protestants. Ed. Holtrop, PN, De Lange F, Roukema R Kampen: Kok. 149-163.

Kierkegaard, S 1949. Die Tagebücher, 1834-1855. München: Kösel.

Kunin, SD 1998. God's Place in the World. Sacred Space and sacred Place in Judaism. Cassell. London and New York.

Lee, SH 2001. Worship on the Edge. Liminality and the Korean American Context. In Making Room at the Table. An invitation to Multicultural Worship. Ed Blount, BK and Tisdale, LT. Westminster: John Knox Press, 96-107.

McFague, S 1978. Speaking in Parables. Philadelphia: Fortress Press.

Mouton, E 2007. Transmitting Hope in the New Testament. Preaching as a Language of Hope. Studia Homiletica 6, Ed Cas Vos, Lucy L Hogan and Johan H Cilliers. Pretoria: Protea Book House 2007. 73-87.

Nel, M 2001. Ek is die verskil. Die invloed van persoonlikheid in die prediking. Bloemfontein: CLF.

Peterson, E 2000. A long Obedience in the Same Direction: Discipleship in an Instant Society. Downers Grove, IL: Inter-Varsity Press.

Richter-Böhne A 1989. Unbekannte Schuld. Politischer Predigt unter allierter Besatzung. Stuttgart: Calwer Verlag.

Ricoeur, P 1975. Parole et symbole. RevSR, 49, 142-161.

Ricoeur, P 1979. Naming God. USQR, 34 (4), 15-27.

Tisdale, LT 2001. Navigating the contemporary worship narrows. Channel markers for deep waters. Making Room at the Table. An Invitation to Multicultural Worship. 
(Ed.) BK Blount and LT Tisdale. Louisville, Kentucky: Westminster John Knox Press, 175-188

Tournier, P 1968. A Place for You. New York, NY: Harper and Row.

Turner V en Turner E, 1978. Image and Pilgrimage in Christian Culture. New York: Columbia University Press.

Van Gennep, A 1909. Les rites de passage. Paris: Emile Nourry.

Van Niekerk, A 1994. Om oor God te praat: Analogiese spreke as skepping en onthulling. Ned Geref Teologiese Tydskrif 35 (2):279-295.

Westermann, C 1974. The role of the Lament in the Theology of the Old Testament. Interpretation 28/4. 20-38.

Wolff, HW 1969. Jahwe und die Götter in der alttestamentlichen Prophetie. Ein Beitrag zur Frage nach der Wirklichkeit Gottes und der Wirklichkeit der Welt. Ev Th 39 Jahrgang. 